\title{
Primary Extragonadal Yolk Sac Tumor Involving Stomach in a Young Child: A Case Report
}

\author{
Faisal R Guru', Saquib Zaffar², Huma Noor², Salma Gull', Gull Muhammad Bhat ${ }^{2}$ \\ 'Department of Pediatric Oncology SKIMS, ${ }^{2}$ Department of Medical Oncology, SKIMS \\ ${ }^{3}$ Department of Pathology, SKIMS
}

\section{A B S T R A C T}

Germ cell tumor (GCT) constitute 2-3\% of childhood malignancies. GCT's are more common in the ovaries and testes than in extragonadal sites. We report a case of primary extragonadal yolk sac tumor of stomach in a two and a half year old child.

JMS: 2019; 22(1):75-77 DOI: https://doi.org/10.33883/jms.v22i2.396

\section{INTRODUCTION}

Germ Cell Tumors (GCTs) in children are uncommon constituting approximately only $3 \%$ of all malignancies in children younger than 15 years of age. Germ cell tumors are a heterogeneous group of malignant tumors with a wide variety of histopathological features. Yolk sac tumor is the predominant variant in newborns and younger children. Extragonadal GCTs arise from local transformation of primordial germ cells which have been misplaced during the migration of these cells through the midline dorsal mesentery in the fourth-sixth week of embryogenesis.

\section{CASE REPORT}

We report a primary yolk sac tumor arising from the stomach of a child. A two and half year-old male child born by normal vaginal delivery, second in birth order with normal developmental milestones presented with an abdominal swelling and malena for 1 month. The swelling was noticed by parents while bathing the child. The swelling was sudden in onset, non-tender and progressively increased in size. On clinical examination the child had

\begin{tabular}{l|l}
\multicolumn{2}{c}{ Access this article online } \\
\hline
\end{tabular}

pallor. On abdomen examination there was a single, smooth, hard, $12 \times 10 \mathrm{~cm}$ mass in the epigastrium and right hypochondrium which was progressively increasing in size, nontender, with round margins. Rest of examination was normal. All routine investigations were within normal limits except liver function test (LFT) which revealed elevated liver enzymes and raised C-reactive protein (CRP) levels. Coagulation profile was normal. USG abdomen was done which showed a large mass arising from the stomach with ascites. Contrast enhanced computed tomography (CECT) of the abdomen showed a large mass present in the gastrosplenic location arising from the wall of the stomach with multiple perilesional deposits and mild ascites and a simple liver cyst (Figure 1).

Serum alpha-feto protein (AFP) levels were found to be

\section{Correspondence:}

Dr. Faisal R Guru, M.D

Assistant Professor, Department of Pediatric Oncology, SKIMS Email:faisal_guru@yahoo.com

How to cite this article: Guru FR, Zaffar S, Noor H, Gull S, Bhat GM. Pure Primary Extragonadal Yolk Sac Tumor involving stomach in a Young Child: A Case Report. jms [Internet]. 2019May27 [cited 2019May27];22(2). Available from: http://www.jmsskims.org/index.php/jms/article/view/396

Received: 12-02-2019 Accepted: 05-04-2019 
markedly raised $(191100 \mathrm{IU} / \mathrm{ml})$ and serum beta human chorionic gonadotropin (HCG) level was normal (1.0 $\mathrm{IU} / \mathrm{ml}$ ). Upper GI endoscopy revealed a sub-mucosal infiltrating lesion involving the fundus and the proximal body of the stomach with central excavation. Biopsy was taken and histopathology revealed yolk sac tumor.

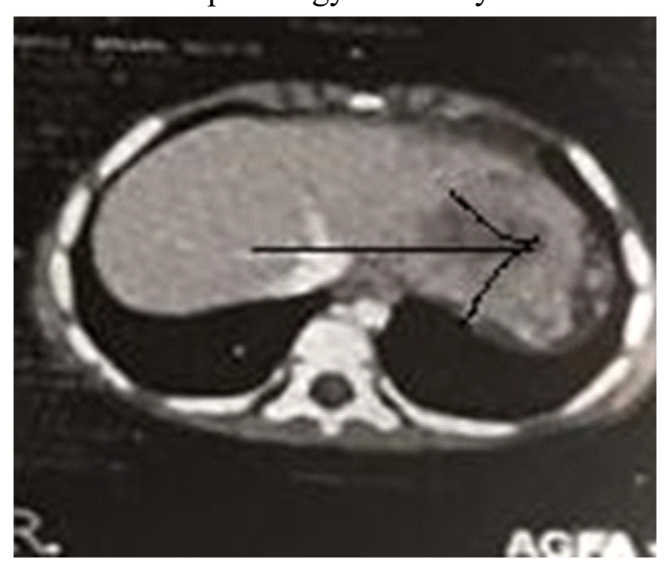

Fig 1: CECT abdomen showing a large mass arising from the wall of the stomach with multiple perilesional deposits

Thus, a diagnosis of extra gonadal germ cell tumor was made and neoadjuvant chemotherapy was administered with BEP (BLEOMYCIN+ ETOPOSIDE+CISPLATIN). Post 1st cycle of BEP, AFP levels reduced to 467IU/ml. Subsequently, patient completed 4 cycles of BEP and reassessment with $\mathrm{CT}$ showed decrease in size of the gastric mass. Patient was operated and a partial gastrectomy was done. Intraoperatively, a huge mass was present in the proximal stomach with no significant loco-regional lymphadenopathy, peritoneal deposits, ascites or liver metastasis. On gross examination of the specimen, there was a large nodular, capsulated grey brown mass in the stomach and measured $10 \times 9 \times 7 \mathrm{~cm}$. Cut surface of the mass was soft, grey-white, with a few cystic spaces filled with brown mucoid fluid, and small areas of hemorrhage were also noted. On microscopy, sections showed tumor cells arranged in a variety of patterns. These tumor cells had a large pleomorphic and vesicular nucleus with prominent nucleoli, marked nuclear atypia and many atypical mitotic figures. The cytoplasm of the tumor cells was vacuolated. At many places, the tumor cells were arranged in glomeruloid structures surrounding a blood vessel (Schiller-Duval bodies) (Figure 2). Areas of hemorrhage were also seen. On staining with PAS, many PAS positive hyaline globules were noted. Immunohistochemistry was done with cytokeratin,SALLA,PLAP,CD117,glipican-3, AE 1/3 and the tumor cells showed diffuse cytoplasmic positivity and as such diagnosis of a primary yolk sac tumor was made. Postsurgery, the patient was planned for two more cycles of cisplatin and etoposide. Following six cycles of chemotherapy, the AFP levels were back to normal (2 $\mathrm{IU} / \mathrm{ml}$ ) and the child is doing well.

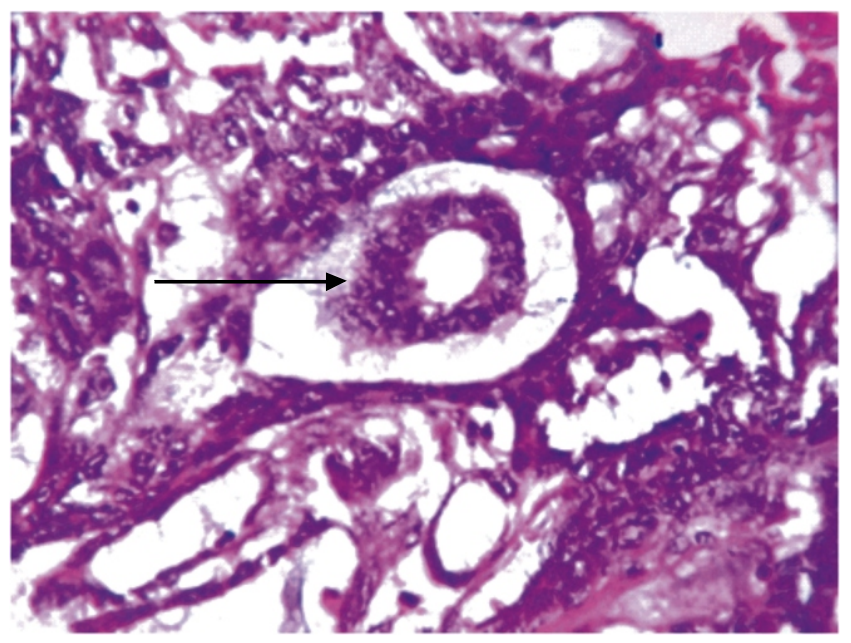

Fig 2: Microscopic picture showing Yolk Sac Tumor with Schiller Duval Body in our case.

\section{DISCUSSION}

GCTs account for approximately $3 \%$ of all malignancies in children younger than 15 years of age $[1,2]$. Histologically, GCTs can occur in pure or mixed form (tumor is composed of two or more histological types), with mixed forms accounting for $32-54 \%$ of all GCTs [3]. GCTs in children show remarkable variability in age, site, presentation and histology [4]. They can be gonadal or extragonadal in site. GCTs in extragonadal sites arise from remnants of progenitor germ cells during its migration to the developing gonadal ridge and constitute $1.5 \%$ of all GCTs in children [5]. These extragonadal tumors usually occur in midline locations (mediastinal, retroperitoneal, sacrococcygeal or cranial) [4]. Klinefelter's syndrome is the only known predisposing factor. So, all diagnostic, therapeutic and prognostic criteria for a primary GCT from the testis apply to a extragonadal GCT as well [7].

Yolk Sac Tumor (YST) also known as "endodermal sinus tumor" or "orchioblastoma" is a type of GCT. YSTs show a bimodal distribution with an increased incidence in the first four years of life and then during the 2 nd to 4 th decade of life. YSTs constitute about $20 \%$ of all malignant GCTs [8]. Pure or mixed YSTs have been seen to occur in extragonadal 
Guru FR; et al; Primary Extragonadal Yolk Sac Tumor

\section{Conflict of interest : Nil.}

Financial Source: Nil

\section{REFERENCES}

1. Gobel U, Schneider DT, Calaminus G, Haas RJ, Schmidt P, Harms D. Germ cell tumors in childhood and adolescence. GPOH MAKEI and the MAHO study groups. Ann Oncol. 2000; 11(3):263-71.

2. Deb M, Mohanty S, Ananthamurthy A, Garg I, Das K. Atypical extragonadal germ cell tumors. J Indian Assoc Pediatric Surg. 2012; 17:9-15.

3. Eble J. Pathology and genetics of tumors of the urinary system and male genital organs. Lyon: IARC Press; 2004; Pp. 237-40.

4. Horton Z, Schlatter M, Schultz S. Pediatric germ cell tumors. Surg Oncol. 2007; 16(3):205-13.

5. Dede M, Pabuccu R, Yagci G, Yenen M, Goktolga U, Gunhan O. Extragonadal yolk sac tumor in pelvic localization. A case report and literature review. Gynecol Oncol. 2004; 92(3):989-91.

6. Shinagare A, Jagannathan J, Ramaiya N, Hall M, Van den Abbeele A. Adult extragonadal germ cell tumors. AJR Am J Roentgenol. 2010; 195(4):W274-W280.

7. Albany C, Einhorn LH. Extragonadal germ cell tumors: clinical presentation and management. CurrOpin Oncol. 2013; 25:26165.

8. Arumugam D, Thandavarayan P, Chidambaram L, Boj S, Marudasalam S. Primary nasopharngeal yolk sac tumor: A case report. JCDR. 2016; 10(5):6-7.
9. Dabbs D. Diagnostic immunohistochemistry. 3rd ed. Philadelphia, PA: Saunders/ Elsevier; 2010; Pp.737739.

10. Roth L, Panganiban W. Gonadal and extragonadal yolk sac carcinomas. A clinicopathologic study of 14 cases. Cancer. 1976; 37(2):812-20.

11. Brodeur G, Howarth C, Pratt C, Caces J, Hustu H. Malignant germ cell tumors in 57 children and adolescents. Cancer. 1981;48(8):1890-98.

12. Lack E, Travis W, Welch K. Retroperitoneal germ cell tumors in childhood. A clinical and pathologic study of 11 cases. Cancer. 1985; 56(3):602-08.

13. Agarwal BR, Patel M, Shah BN, Currimbhoy Z, Waingankar VS, Meisheri I, et al. Endodermal sinus tumor: report of 12 cases. Indian Pediatric. 1993; 30:1321-25.

14. Murat E, Dagdemir A, Bilgici M, Sullu Y. Primary yolk sac tumor of the retroperitoneal region. Contemp Onco .2013; 17(6):53032.

15. Choudaha P, Likhar KS, Gupta SG, Patle Y, Hazari RA. Extragonadal retroperitoneal pure yolk sac tumour. PJSR. 2014:7(2):47-50.

16. Nisar A Bhat, Aftab S. Chishti et.al Gastric immature Teratoma Saudi Med J 2007:Vol 2.28(6).

17. Shakeel A Malik, Nisar A. Bhat et. Al Malignant gastric Teratoma A Case Report. JK Practitioner. Vol.5 No.2, April June 1998. 